\title{
Pharmacokinetics and isolated hepatocyte
}

\section{Abstract}

Hepatic metabolism is an important contributor affecting the bioavailability of chemicals. Today isolated hepatocytes are widely used to study the biological assessment of xenobiotics and drug metabolisms. In this regard, methods have been developed to implement systems to evaluate in vitro biological properties of natural and synthetic compounds. This mini review will provide a brief introduction of two isolated hepatocyte preparation methods.

Keywords: hepatocytes, drug metabolism, bioavailability, xenobiotics
Volume 3 Issue I - 2017

Javad Khalili Fard

Pharmacology and Toxicology Department, Tabriz University of Medical Sciences, Iran

Correspondence: Javad Khalili Fard, Faculty of Pharmacy, Pharmacology and Toxicology Department, Tabriz University of Medical Sciences, Daneshgah Street, Tabriz, Iran, Tel +984133372250I,Email Javad.khalilifard@yahoo.com

\section{Introduction}

Two main groups of collagen in the body which is present in an extracellular matrix have been identified: fibrillar (Type I, II, III, V, XI) and non-fibrillar collagen. ${ }^{1}$ A mixture of collagens is embedded in the collagenous fibrillar network of the liver. Approximately $80 \%$ of the total hepatic collagen is made up of type I and type III collagens. ${ }^{2}$ Moreover, these types of collagen are present in the renal interstitium and blood vessels. ${ }^{3}$ By means of this structural protein the hepatocytes are attached to other neighboring hepatocytes. Knowledge about this key component has shaped the methods of isolation of not only hepatocytes but also other mammalian cells such as kidney glomeruli.

Clostridium species excrete collagenases which break the peptide bonds in collagen and contribute to its pathogenesis. This enzyme is widely used to isolate both parenchymal and non-parenchymal cells. Non-parenchymal cells and Kupffer cells could be isolated from liver by pronase and collagenase perfusion.

Table I List of chemicals used in Method I

\section{Hepatocyte isolation methods}

Method 1: In this method liver is perfused continuously with SC-1 solution at $37^{\circ} \mathrm{C}$ for $5 \mathrm{~min}$ followed by $15 \mathrm{~min}$ perfusion with $0.03 \%$ collagenase which is prepared by dissolving in SC-2 solution (Table 1). After these perfusion procedures, the liver is cut, and the cells are suspended in Geys balance salt solution (GBSS). The cell suspension is filtered using a steel mesh and centrifuged at $50 \mathrm{~g}$ for $1 \mathrm{~min}$. The cell pellet was resuspended in GBSS solution, and the washing procedure was repeated three times. ${ }^{4}$

Method 2: Calcium-free Hanks balanced salt solution with HEPES (HBSSH) is prepared by combining $100 \mathrm{ml}$ of each stock solution (A,B,C,D) with $600 \mathrm{ml}$ deionized, distilled water and $\mathrm{pH}$ is adjusted to 7.5 by adding $\mathrm{NaOH}$. Deionized, distilled water is added to each stock up to $1 \mathrm{~L}$ (Table 2).

\begin{tabular}{|c|c|c|c|c|c|c|c|c|c|}
\hline \multicolumn{10}{|c|}{$\mathrm{Ph} 7.25$ (All in Mg/L) } \\
\hline \multirow[t]{2}{*}{ SC-I Solution } & $\mathrm{NaCl}$ & $\mathrm{KCl}$ & $\mathrm{NaH}_{2} \mathrm{PO}_{4} \cdot \mathrm{H}_{2} \mathrm{O}$ & $\mathrm{Na}_{2} \mathrm{HPO}_{4}$ & HEPES & $\mathrm{NaHCO}_{3}$ & EGTA & Glucose & \\
\hline & 8,000 & 400 & 88.7 & 120.45 & 2,380 & 350 & 190 & 900 & \\
\hline \multirow[t]{2}{*}{ SC-2 Solution } & $\mathrm{NaCl}$ & $\mathrm{KCl}$ & $\mathrm{NaH}_{2} \mathrm{PO}_{4} \cdot \mathrm{H}_{2} \mathrm{O}$ & $\mathrm{Na}_{2} \mathrm{HPO}_{4}$ & HEPES & $\mathrm{CaCl}_{2} \cdot 2 \mathrm{H}_{2} \mathrm{O}$ & & & \\
\hline & 8,000 & $\mathrm{KCl}$ & 88.7 & 120.45 & 2,380 & 560 & & & \\
\hline \multirow[t]{2}{*}{$\begin{array}{l}\text { Geys Balance } \\
\text { Salt Solution }\end{array}$} & $\mathrm{NaCl}$ & $\mathrm{KCl}$ & $\mathrm{MgCl}_{2} \cdot 6 \mathrm{H}_{2} \mathrm{O}$ & $\mathrm{MgSO}_{4} \cdot 7 \mathrm{H}_{2} \mathrm{O}$ & $\mathrm{NaH}_{2} \mathrm{PO}_{4}$ & $\mathrm{KH}_{2} \mathrm{PO}_{4}$ & Glucose & $\mathrm{NaHCO}_{3}$ & $\mathrm{CaCl}_{2} \cdot 2 \mathrm{H}_{2} \mathrm{O}$ \\
\hline & 8,000 & 370 & 210 & 70 & 120 & 30 & 991 & 227 & 225 \\
\hline
\end{tabular}

Table 2 List of chemicals used in Method 2

\begin{tabular}{|c|c|c|c|c|c|c|c|c|}
\hline \multicolumn{9}{|c|}{ All in $\mathbf{G} / \mathbf{L}$} \\
\hline Stock A & Stock B & & & Stock C & & & & Stock D \\
\hline Glucose & $\mathrm{MgCl}_{2} \cdot 6 \mathrm{H}_{2} \mathrm{O}$ & $\mathrm{MgSO}_{4} \cdot 7 \mathrm{H}_{2} \mathrm{O}$ & $\mathrm{NaCl}$ & $\mathrm{KCl}$ & $\mathrm{KH}_{2} \mathrm{PO}_{4}$ & $\mathrm{Na}_{2} \mathrm{HPO}_{4}$ & Phenol Red & HEPES \\
\hline $10 \mathrm{~g}$ & $\lg$ & $\lg$ & $80 \mathrm{~g}$ & $4 \mathrm{~g}$ & $0.6 \mathrm{~g}$ & $0.49 \mathrm{~g}$ & $0.1 \mathrm{~g}$ & $48 \mathrm{~g}$ \\
\hline \multicolumn{9}{|c|}{ Collagenase stock buffer (pH 7.4) } \\
\hline $\mathrm{NaCl}$ & $\mathrm{KCl}$ & $\mathrm{CaCl}_{2} \cdot 2 \mathrm{H}_{2} \mathrm{O}$ & & HEPES & & & $\mathrm{NaOH}(\mathrm{IN})$ & \\
\hline $3.9 \mathrm{~g}$ & $0.5 \mathrm{~g}$ & $0.7 \mathrm{~g}$ & & $24 \mathrm{~g}$ & & & $66 \mathrm{ml}$ & \\
\hline
\end{tabular}


To prepare $1 \%$ collagenase buffer solution dissolve $50 \mathrm{mg}$ collagenase type I in $50 \mathrm{ml}$ collagenase stock buffer. To obtain non parenchymal cells pronase which effectively digest parenchymal cells could be used. After these procedures the liver is embedded in a dish containing HBSSH. The cell suspension is centrifuged at $50 \mathrm{~g}$ for 4 min at $4^{\circ} \mathrm{C}$. Then supernatant is discarded and cells are resuspended in fresh medium. ${ }^{5}$

\section{Conclusion}

Isolated hepatocytes provide a suitable tool which facilitates evaluating not only chemical metabolisms but also the effects of drugs on organelles in both human and animal cells. In various studies cells viability was between $85 \%$ and $97 \% .{ }^{6}$ Since in method 1 and 2 the weight/volume percentage concentration of the collagenase solution is respectively 0.03 and 1 and the washing time period differ in both methods, it is suggested that the efficacy of different methods should be simultaneously assessed in a similar experiment.

\section{Acknowledgements}

None.

\section{Conflict of interest}

The author declares no conflict of interest.

\section{References}

1. Fratzl P. Collagen: Structure and Mechanics. Germany: Springer; 2008.

2. Aycock RS, Seyer JM. Collagens of normal and cirrhotic human liver. Connect Tissue Res. 1989;23(1):19-31.

3. Yoshioka K, Tohda M, Takemura T, et al. Distribution of type I collagen in human kidney diseases in comparison with type III collagen.J Pathol. 1990;162(2):141-148.

4. Tamaki N, Hatano E, Taura K, et al. CHOP deficiency attenuates cholestasis-induced liver fibrosis by reduction of hepatocyte injury. $\mathrm{Am}$ J Physiol Gastrointest Liver Physiol. 2008;294(2):G498-505.

5. Charles AT, John MF. In vitro Biological Systems: Methods in Toxicology. USA: Elsevier; 2016. 592 p.

6. Carvalho M, Milhazes N, Remião F, et al. Hepatotoxicity of 3, 4-methylenedioxyamphetamine and $\alpha$-methyldopamine in isolated rat hepatocytes: formation of glutathione conjugates. Arch Toxicol. 2004;78(1):1624. 